\title{
A multicenter study of biopsied oral and maxillofacial lesions in a Brazilian pediatric population
}

Leni Verônica de Oliveira SILVA(a) José Alcides Almeida ARRUDA(a)

Stephanie Joana MARTELLI(b)

Camila de Nazaré Alves de

Oliveira KATO(a)

Laiz Fernanda Mendes NUNES(a)

Ana Carolina Uchoa VASCONCELOS(b)

Sandra Beatriz Chaves TARQUINIO(b)

Ana Paula Neutzling GOMES(b)

Ricardo Santiago GOMEZ(a)

Ricardo Alves MESQUITA(a)

Marcia Maria Fonseca da SILVEIRA(c)

Ana Paula Veras SOBRAL(c)

(a) Universidade Federal de Minas Gerais UFMG, School of Dentistry, Department of Oral Surgery and Pathology,

Belo Horizonte, MG, Brazil.

(b) Universidade Federal de Pelotas - UFPel, School of Dentistry, Diagnostic Center for Oral Diseases, Pelotas, RS, Brazil.

(c) Universidade de Pernambuco - UPE, School of Dentistry, Department of Oral and Maxillofacial Pathology, Camaragibe, PE, Brazil.

Declaration of Interest: The authors certify that they have no commercial or associative interest that represents a conflict of interest in connection with the manuscript.

\section{Corresponding Author:}

José Alcides Almeida Arruda

E-mail: alcides_almeida@hotmail.com.

hitps://doi.org/10.1590/1807-3107bor-2018.vol32.0020

Submitted: July 13, 2017

Accepted for publication: Jan 31, 2018

Last revision: Feb 08, 2018
Abstract: The aim of this study was to investigate the prevalence of oral and maxillofacial lesions among children from representative regions of Brazil. A retrospective descriptive study was conducted. Biopsy records comprising the period from 2000 to 2015 were obtained from the archives of three Brazilian oral pathology referral centers. A total of 32,506 biopsy specimens were analyzed, and specimens from 1,706 children aged 0-12 years were selected. Gender, age, anatomical location and histopathological diagnosis were evaluated. Descriptive statistics was carried out. Likelihood ratio tests were used to evaluate the association between the categorical variables. The level of significance was set at 0.05 . The post-hoc test was used to identify the subgroups that significantly differed from one another, and the Bonferroni correction was applied. A total of 1,706 oral and maxillofacial lesions were diagnosed in pediatric patients, including $51.9 \%$ girls. Oral mucocele was the most prevalent reactive/inflammatory lesion (64\%). The most commonly affected sites were the lips (34.5\%) and mandible (19.9\%). A significant association was observed between age and the group of lesions of the oral cavity $(p<0.001)$, and between age and anatomical location ( $p<0.001)$. Pediatric oral and maxillofacial lesions were frequent and showed wide diversity, with the prevalence of mucocele. Knowledge of oral lesions is important for pediatric dentists worldwide, since it provides accurate data for the diagnosis and oral health of children.

Keywords: Pathology, Oral; Mouth Mucosa; Pediatrics; Child; Epidemiology.

\section{Introduction}

Children represent the future, and ensuring their healthy growth and development should be a major concern of all societies. Newborns and children are vulnerable to malnutrition and infectious diseases, many of which can be effectively prevented or treated. It is estimated that $43 \%$ of the pediatric population younger than 5 years in low- and middle-income countries (249 million) are at risk of not reaching their developmental potential. ${ }^{1}$

The current estimated population of Brazil is 207 million inhabitants, $14.3 \%$ of which are children younger than 10 years. The proportion of children has decreased over a period of 15 years from 19.9\% (in 2000) to 14.6\% (in 2016). ${ }^{2}$ This decline can be explained by the increase in the urban population, since 
the birth rate is much lower in cities, because of the progressive integration of women into the labor market, and the dissemination of birth control. Furthermore, the social cost of maintaining and educating children is very high, particularly in urban centers. ${ }^{2}$

The average global birth rate has fallen by half since 1970. Forty years ago, each woman had 4.7 children, whereas the current average is $2.5 .^{3}$ In view of this decline in natality, the pediatric population must not be neglected, because it represents the future world population. For this reason, the number of new cases of biopsied oral lesions in this population deserves the attention of public health policies, so that these lesions can be diagnosed and treated early to promote the quality of life of this population.

The world population is expected to reach 9.7 billion by $2050 .^{3}$ This increase is accompanied by a high incidence of oral and systemic diseases. Studies on the epidemiology of oral lesions, based on biopsies obtained worldwide from pediatric patients, have detected a frequency of such diseases, ranging from $5.2 \%$ to $12.8 \%$ of the total number of biopsies. $4,5,6,7,7$ Martins-Filho et al. ${ }^{9}$ evaluated 4,690 oral biopsies, 564 from children, and found a variation in the prevalence of oral lesions, including a relationship between age and sex. Nevertheless, the number of epidemiological studies on pediatric patients is still limited, and further information is needed and important. ${ }^{9,10}$

The interest in the health of pediatric patients has encouraged new scientific studies. ${ }^{9,11,12,13,14,15,16,17,18,19} \mathrm{In}$ this respect, epidemiological studies based on the histopathological records of oral and maxillofacial biopsies have provided more accurate and conclusive data. ${ }^{4,5,7,8,9,12,13,14,19}$ The objective of the present study was to determine the prevalence of oral lesions in pediatric patients, by evaluating the biopsy records of oral and maxillofacial pathology centers located in different regions of Brazil.

\section{Methodology}

\section{Study design and ethical issues}

In a retrospective study (2000-2015), 32,506 histopathological records of oral and maxillofacial biopsies were analyzed. The records were obtained from three oral diagnostic referral centers in Brazil:
Department of Oral Pathology, School of Dentistry of the University of Pernambuco (Northeast region); Department of Oral Surgery and Pathology, School of Dentistry of the Federal University of Minas Gerais (Southeast region); and Diagnostic Center for Oral Diseases of the Federal University of Pelotas (South region). The study was approved by the local Ethics Committee (Approval No. 016/2003). The patients' identity remained anonymous according to the Declaration of Helsinki.

\section{Sample}

A total of 1,706 biopsy records were collected from patients aged 0 to 12 years. The oral and maxillofacial lesions were analyzed regarding gender, age, anatomical location, and histopathological diagnosis. The patients were stratified by age $(0-4,5-8$ and $9-12$ years) to evaluate the distribution of lesions according to developmental stage (preschool, school age, and preadolescence). The anatomical sites involved were divided into gingiva, lips, maxilla, mandible, palate, floor of the mouth, tongue, cheek mucosa, and extraoral site. Exclusion criteria were the lack of information on age, gender or histopathological diagnosis.

Benign and malignant tumors were classified according to the 2017 classification of the World Health Organization. ${ }^{20}$ Other lesions were classified according to the Textbook of Oral and Maxillofacial Pathology. ${ }^{21}$ The histopathological diagnoses were categorized as follows: infectious diseases (group 1), benign neoplasms (group 2), malignant neoplasms (group3), immune diseases (group 4), reactive/inflammatory lesions (group 5), odontogenic and non-odontogenic cysts (group 6), pigmented lesions and calcifications (group 7), potentially malignant oral disorders (group 8), and non-neoplastic bone lesions (group 9).The cases were analyzed by three independent oral and maxillofacial pathologists with over 20 years of experience. Immunohistochemical analysis was performed when routine staining (hematoxylin-eosin) was not sufficient to establish the final diagnosis of the lesions.

\section{Data analysis}

Statistical analysis was performed using the Statistical Package for the Social Sciences (SPSS) software, version 17.0 (SPSS Inc., Chicago, IL, USA), and 
descriptive statistics was also carried out. Likelihood ratio tests were used to evaluate the association between the categorical variables. The level of significance was set at 0.05 . The post-hoc test was used to identify the subgroups that significantly differed from one another. The Bonferroni correction was applied, and the level of significance was set at 0.002 .

\section{Results}

A total of 32,506 patients were diagnosed with oral and maxillofacial lesions at the centers studied; 1,706 (5.2\%) of these patients were 0 to 12 years old. Among the cases selected, 21.0\% $(n=358)$ were from the University of Pernambuco, 55.7\% ( $\mathrm{n}=951)$, from the Federal University of Minas Gerais, and 23.3\% ( $n=397$ ), from the Federal University of Pelotas.

The female gender corresponded to $51.9 \%(n=885)$ of the cases. The highest frequency of lesions (60.7\%) was observed in the 9-12-year age group. The lesions affected different sites, the most common of which were the lips (34.5\%), mandible (19.9\%), and maxilla (13.5\%) (Table 1).

The most prevalent groups were reactive/ inflammatory lesions (51.8\%) and odontogenic and non-odontogenic cysts $(21.3 \%)$. The most common oral lesions within each group were infectious diseases: verruca vulgaris (89.2\%); benign neoplasms: odontoma (26.6\%); malignant neoplasms: squamous cell carcinoma (17.4\%); immunological diseases: graft-versus-host disease (66.7\%); inflammatory/ reactive lesions: mucocele (64\%); odontogenic and non-odontogenic cysts: dentigerous cyst $(40.8 \%)$; pigmented and calcified lesions: melanocytic nevi (55.5\%); potentially malignant oral disorders: actinic cheilitis (50\%); and non-neoplastic bone lesions: benign fibro-osseous lesions (31.5\%) (Table 1).

Among the neoplasms diagnosed in pediatric patients, $16.9 \%$ were benign tumors and $1.3 \%$ were malignant neoplasms. The most prevalent benign neoplasms were odontoma (26.6\%), squamous cell papilloma (14.5\%), and ameloblastoma (7.6\%). Although not common in children, different histological types of malignant neoplasms were diagnosed: oral squamous cell carcinoma $(n=4)$, adenocarcinoma, $\operatorname{NOS}(n=$ 3), mucoepidermoid carcinoma $(n=3)$, Langerhans
Table 1. Distribution of age, gender, diagnosis, and anatomical location of oral lesions in the pediatric patients studied.

\begin{tabular}{|c|c|c|}
\hline Variables & $\mathrm{n}$ & $\begin{array}{c}\% \\
\text { (all cases) }\end{array}$ \\
\hline \multicolumn{3}{|l|}{ Age } \\
\hline $0-4$ years & 138 & 8.1 \\
\hline $5-8$ years & 532 & 31.2 \\
\hline $9-12$ years & 1,036 & 60.7 \\
\hline \multicolumn{3}{|l|}{ Gender } \\
\hline Male & 821 & 48.1 \\
\hline Female & 885 & 51.9 \\
\hline \multicolumn{3}{|l|}{ Diagnosis } \\
\hline Group 1 (Infectious diseases) & 37 & 2.2 \\
\hline Group 2 (Benign neoplasms) & 289 & 16.9 \\
\hline Group 3 (Malignant neoplasms) & 23 & 1.3 \\
\hline Group 4 (Immunological diseases) & 15 & 0.9 \\
\hline Group 5 (Inflammatory/reactive lesions) & 884 & 51.8 \\
\hline $\begin{array}{l}\text { Group } 6 \text { (Odontogenic and } \\
\text { non-odontogenic cysts) }\end{array}$ & 363 & 21.3 \\
\hline $\begin{array}{l}\text { Group } 7 \text { (Pigmented and } \\
\text { calcified lesions) }\end{array}$ & 18 & 1.1 \\
\hline $\begin{array}{l}\text { Group } 8 \text { (Potentially malignant } \\
\text { oral disorders) }\end{array}$ & 4 & 0.2 \\
\hline $\begin{array}{l}\text { Group } 9 \text { (Non-neoplastic } \\
\text { bone lesions) }\end{array}$ & 73 & 4.3 \\
\hline \multicolumn{3}{|l|}{ Anatomical location } \\
\hline Gingiva & 118 & 6.9 \\
\hline Lips (vermilion and labial mucosa) & 587 & 34.5 \\
\hline Maxilla & 230 & 13.5 \\
\hline Mandible & 340 & 19.9 \\
\hline Palate & 38 & 2.2 \\
\hline Floor of the mouth & 60 & 3.5 \\
\hline Tongue & 161 & 9.4 \\
\hline Cheek mucosa & 61 & 3.6 \\
\hline Extraoral region & 31 & 1.8 \\
\hline Not informed & 80 & 4.7 \\
\hline
\end{tabular}

cell histiocytosis $(n=3)$, rhabdomyosarcoma $(n=2)$, Burkitt's lymphoma $(n=2)$, leiomyosarcoma $(n=2)$, primitive neuroectodermal tumor $(n=1)$, malignant histiocytoma $(n=1)$, small-cell carcinoma $(n=1)$, and acute lymphoblastic leukemia $(\mathrm{n}=1)$.

A significant association was observed between age and the lesion groups studied $(\mathrm{p}<0.001)$, and between age and anatomical location $(\mathrm{p}<0.001)$. No significant result was obtained for age and gender $(p=0.391)$. Children aged 0-4 years had a significantly lower frequency of benign neoplasms ( $p=0.001)$. Individuals aged 5-8 and 9-12 years had a significantly higher 
frequency of inflammatory/reactive lesions than individuals aged $0-4$ years $(\mathrm{p}<0.001)$, and children aged 9-12 years had a significantly higher frequency of odontogenic and non-odontogenic cysts ( $p<0.001)$. The frequency of lesions on the lips was significantly higher in children aged 5-8 and 9-12 years than in those aged $0-4$ years $(\mathrm{p}<0.001)$. Lastly, children aged 9-12 years showed a significantly higher frequency of diseases in the maxilla than individuals aged $0-4$ and $5-8$ years $(p=0.001)$ (Table 2$)$.

Brazilian studies involving pediatric patients conducted in different regions of the country have found variations in geographic distribution, prevalence, age, group, period of data collection, number of lesions and malignant lesions (Table 3).

\section{Discussion}

The prevalence of different oral lesions has been reported over the years. ${ }^{6,14,15,17,18,19,22,23,24,25,26,27,28,29}$ There are only three multicenter studies similar to the present one that analyzed data from different cities to establish Brazil's pediatric epidemiological profile., ${ }^{9,13,15}$ In retrospective epidemiological studies of oral lesions from children's biopsies, there was no consensus regarding the classification of oral lesions into groups and subgroups, age groups, or the anatomical sites involved. There is no agreement between studies because of the lack of a standardized pediatric age range, and because the studies did not use the same international classification of oral lesions. ${ }^{6,923}$ Despite

Table 2. Frequency of oral lesions in the pediatric patients studied.

\begin{tabular}{|c|c|c|c|c|}
\hline \multirow{2}{*}{ Variables } & \multicolumn{3}{|c|}{ Age n (\%) } & \multirow{2}{*}{ p-value } \\
\hline & $0-4$ years & $5-8$ years & $9-12$ years & \\
\hline \multicolumn{5}{|l|}{ Gender } \\
\hline Male & $59(42.8)$ & $262(49.2)$ & $500(48.3)$ & $0.391^{*}$ \\
\hline Female & $79(57.2)$ & $270(50.8)$ & $536(51.7)$ & \\
\hline Total & $138(100)$ & $532(100)$ & $1,036(100)$ & \\
\hline \multicolumn{5}{|l|}{ Diagnosis } \\
\hline Group 1 (Infectious diseases) & $1(0.7)$ & $16(3.0)$ & $20(1.9)$ & \\
\hline Group 2 (Benign neoplasms) & $38(27.5)^{* *}$ & $71(13.3)$ & $180(17.4)$ & \\
\hline Group 3 (Malignant neoplasms) & $6(4.3)$ & $5(0.9)$ & $12(1.2)$ & \\
\hline Group 4 (Immunological diseases) & $0(0.0)$ & $2(0.4)$ & $13(1.2)$ & \\
\hline Group 5 (Inflammatory/reactive lesions) & $68(49.3)$ & $319(60.0)^{* *}$ & $497(48.0)^{* *}$ & $<0.001^{*}$ \\
\hline Group 6 (Odontogenic and non-odontogenic cysts) & $20(14.5)$ & $96(18.1)$ & $247(23.8)^{* *}$ & \\
\hline Group 7 (Pigmented and calcified lesions) & $3(2.2)$ & $5(0.9)$ & $10(1.0)$ & \\
\hline Group 8 (Potentially malignant oral disorders) & $2(1.5)$ & $0(0.0)$ & $2(0.2)$ & \\
\hline Group 9 (Non-neoplastic bone lesions) & $0(0.0)$ & $18(3.4)$ & $55(5.3)$ & \\
\hline Total & $138(100)$ & $532(100)$ & $1,036(100)$ & \\
\hline \multicolumn{5}{|l|}{ Anatomical location } \\
\hline Gingiva & $16(11.6)$ & $35(6.6)$ & $67(6.5)$ & \\
\hline Lips (vermilion and labial mucosa) & $41(29.7)$ & $223(41.9)^{* *}$ & $323(31.2)^{* *}$ & $<0.001^{*}$ \\
\hline Maxilla & $13(9.4)$ & $56(10.5)$ & $161(15.5)^{* *}$ & \\
\hline Mandible & $23(16.7)$ & $90(16.9)$ & $227(21.9)$ & \\
\hline Palate & $1(0.7)$ & $12(2.3)$ & $25(2.4)$ & \\
\hline Floor of the mouth & $7(5.1)$ & $23(4.3)$ & $30(2.9)$ & \\
\hline Tongue & $16(11.6)$ & $54(10.2)$ & 91 (8.8) & \\
\hline Cheek mucosa & $7(5.1)$ & $12(2.3)$ & $42(4.1)$ & \\
\hline Extraoral region & $6(4.3)$ & $4(0.7)$ & $21(2.0)$ & \\
\hline Not informed & $8(5.8)$ & $23(4.3)$ & $49(4.7)$ & \\
\hline Total & $138(100)$ & $532(100)$ & $1,036(100)$ & \\
\hline
\end{tabular}

"Likelihood Ratio. Significance level < 0.05; "Statistical difference using Post-hoc test and Bonferroni correction. Significance level $<0.002$. 
Table 3. Brazilian studies of oral and maxillofacial pathology in pediatric patients.

\begin{tabular}{|c|c|c|c|c|c|c|c|}
\hline Author & $\begin{array}{c}\text { Year of } \\
\text { publication }\end{array}$ & State & $\begin{array}{l}\text { Study } \\
\text { duration } \\
\text { (years) }\end{array}$ & Age group & $\begin{array}{l}\text { Number of } \\
\text { lesions }\end{array}$ & $\begin{array}{l}\text { Most prevalent } \\
\text { lesion }(\%)^{a}\end{array}$ & $\begin{array}{c}\text { Most prevalent } \\
\text { malignant } \\
\text { lesion (\%) }\end{array}$ \\
\hline Cavalcante et al. ${ }^{22}$ & 1999 & São Paulo & - & $0-14$ y & 370 & $\begin{array}{c}\text { Mucocele } \\
(25.4)\end{array}$ & $\begin{array}{l}\text { Lymphoma } \\
\quad(0.5)\end{array}$ \\
\hline Maia et al. ${ }^{23}$ & 2000 & Minas Gerais & 42 & $21 \mathrm{mo}-12 \mathrm{y}$ & 1,018 & $\begin{array}{l}\text { Dentigerous } \\
\text { cyst (12.8) }\end{array}$ & $\mathrm{BL}(0.8)$ \\
\hline Sousa et al. ${ }^{24}$ & 2002 & São Paulo & 15 & $0-14$ y & 2,356 & $\begin{array}{c}\text { Mucocele } \\
(13.5)\end{array}$ & $\mathrm{LCH}(0.6)$ \\
\hline Lima et al. ${ }^{7}$ & 2008 & Rio Grande do Sul & 20 & $0-14$ y & 625 & $\begin{array}{c}\text { Mucocele } \\
(17.2)\end{array}$ & $\begin{array}{c}\text { RMS }(0.3) ; \\
\text { NB }(0.3) ; \mathrm{LCH} \\
(0.3)\end{array}$ \\
\hline Vale et al. ${ }^{12}$ & 2013 & Pernambuco & 11 & $0-18$ y & 315 & $\begin{array}{c}\text { Mucocele } \\
(33.3)\end{array}$ & - \\
\hline Pessôa et al. ${ }^{13}$ & 2015 & Bahia & 15 & $0-19 y$ & 360 & $\begin{array}{c}\text { Mucocele } \\
\text { (14.1) }\end{array}$ & CS (0.3) \\
\hline Martins-Filho et al. ${ }^{9}$ & 2015 & $\begin{array}{l}\text { Sergipe and } \\
\text { Pernambuco }\end{array}$ & 18 & $0-18$ y & 564 & $\begin{array}{c}\text { Mucocele } \\
(24.4)\end{array}$ & $\begin{array}{c}\text { MEC (0.2); OS } \\
(0.2) ; \text { MPNST } \\
(0.2)\end{array}$ \\
\hline Cavalcante et al. ${ }^{11}$ & 2016 & Ceará & 12 & $0-16$ y & 1,240 & $\begin{array}{l}\text { Mucocele } \\
(27.1)\end{array}$ & $7^{*}(0.6)$ \\
\hline Ataíde et al. ${ }^{14}$ & 2016 & São Paulo & 15 & $0-16$ y & 2,539 & $\begin{array}{c}\text { Mucocele } \\
(37.1)\end{array}$ & $\begin{array}{c}\mathrm{LCH}(33.3) ; \\
\text { lymphomas } \\
(33.3)\end{array}$ \\
\hline Present study & 2018 & $\begin{array}{l}\text { Pernambuco, } \\
\text { Minas Gerais and } \\
\text { Rio Grande do Sul }\end{array}$ & 16 & $0-12$ y & 1,706 & $\begin{array}{c}\text { Mucocele } \\
(28.9)\end{array}$ & $\operatorname{SCC}(0.2)$ \\
\hline
\end{tabular}

BL: Burkitt's lymphoma; CS: chondrosarcoma; LCH: Langerhans cell histiocytosis; MEC: mucoepidermoid carcinoma; MPNST: malignant peripheral nerve sheath tumor; mo: months; NB: neuroblastoma; OS: osteosarcoma; RMS: rhabdomyosarcoma; SCC: squamous cell carcinoma; y: year(s). aPercentage of the whole sample; ${ }^{*}$ The authors did not mention the lesions.

the disagreement in the classification of oral and maxillofacial lesions, age group and anatomical site, mucocele is the most prevalent lesion in children aged 0 to 12 years.

Brazil is the largest country in South and Latin America, and the fifth largest country in the world, in terms of population and area. ${ }^{2}$ The three referral centers with diagnostic services in oral and maxillofacial pathology are located in different geographical regions of the country. In the Brazilian states of Pernambuco, Minas Gerais and Rio Grande do Sul (geographical areas: 98,312 km²; 586,528 km²; $281,748 \mathrm{~km}^{2}$, respectively), children aged 0 to 12 years account for $10.54 \%, 8.97 \%$, and $8.26 \%$ of the population, respectively. ${ }^{2}$ Studies involving pediatric patients have been conducted in different regions, and a comparison of the lesions recorded in this population has revealed variations in prevalence and geographic distribution. $79,11,12,13,14,23,24,25$ However, the advantage of histopathological studies is that this approach is more accurate than a clinical diagnosis, which, albeit very important, is unable to establish the final diagnosis in many cases. $12,23,24$

In the present study, the prevalence of oral lesions in children was $5.2 \%$, whereas this prevalence ranged from 5 to $8 \%$ in other studies. ${ }^{16,19,23}$ This variation is probably related to differences in the study design, including the study duration, a higher age limit, the demand for healthcare, the geographic region, and culture of the country. $12,13,14,16,17,18,19,22,27,28,29$ Most studies have reported a higher frequency of oral lesions among female patients $\mathrm{s}^{8,11,13,17}$, whereas others have 
found a higher frequency among male patients. ${ }^{9,12,16}$ A similar occurrence of oral lesions in both male and female patients was observed in the present study.

Age stratification was performed to demonstrate the distribution of diseases according to different age groups. The results showed that children in the preadolescent stage are more exposed and more susceptible to developing oral lesions than those of preschool age, thus explaining the higher incidence of oral and maxillofacial lesions in this stage, and confirming the data reported about Brazil as a developing country. The frequency of oral lesions was higher in the 9-12-year age group. Jaafari-Ashkavandi and Ashraf ${ }^{18}$ also observed a higher frequency of lesions at a pediatric age approaching 12 years. The rapid development of children and adolescents affects the growth potential of neoplasms and cysts, in addition to rendering this population more susceptible to developing inflammatory lesions. ${ }^{28}$ This phase is characterized by intense odontogenic activity, a fact that maybe related to the occurrence of numerous lesions.

A total of $51.8 \%$ of the children were diagnosed with inflammatory lesions, particularly mucocele, pyogenic granuloma and ranula, and 289 (16.9\%) children were diagnosed with some type of benign neoplasm, the most prevalent of which were odontomas, squamous cell papillomas and ameloblastomas. The frequency of cysts was higher than that of benign neoplasms; $363(21.3 \%)$ children had some cystic lesions, the most common being dentigerous cysts, odontogenic cysts, NOS, and radicular cysts. These data show that the group of cysts of the oral cavity, especially dentigerous cysts, are prevalent in the 9-12-year age group. Cysts are usually associated with the lower third molars and upper canines, and the treatment method chosen should take into consideration the age of the patient and the stage of rhizogenesis of the tooth involved. ${ }^{21}$

The oral and maxillofacial lesions diagnosed involved different anatomical sites. The lips were the most commonly affected site, representing $34.5 \%$ of the lesions, a finding also reported in other studies. ${ }^{12,13,16}$ The high incidence of mechanical traumas, such as chronic lip biting, cheek suction and parafunctional habits, is related to the occurrence of the diseases mentioned above.
Inflammatory/reactive lesions such as mucocele and ranula are the most prevalent lesions in childhood ${ }^{7,9,11,12,13,14,23}$, and were the most common in all age groups studied. Oral mucocele is a benign lesion of the salivary glands, whose etiopathogenesis is commonly associated with parafunctional habits and traumas. A female predilection has been reported, and the most commonly affected site is the lower lip. ${ }^{8,11}$

Cysts were the second most prevalent lesions in this study. According to Prockt et al. ${ }^{30}$, cysts account for $7-13 \%$ of all lesions diagnosed in the oral cavity, and show a predilection for the maxilla. However, in the present study, the frequency of cysts was $21.3 \%$, and the mandible was the most affected site. Dentigerous cysts were the most prevalent lesions of this group, followed by the histopathological diagnosis of odontogenic cysts, NOS. Although the accurate diagnosis of odontogenic cysts is based on clinical, radiographic and histological findings, this information is not always available to oral pathologists. ${ }^{24}$ The prevalence of periapical lesions could be underestimated, since some specimens, such as radicular cysts, which accounted for $14.9 \%$ of cystic lesions in the present study, are usually not submitted to histologic examination. ${ }^{9}$ Zuñiga et al. ${ }^{19}$ found radicular cysts to be the most prevalent cystic lesions, probably because of the more advanced age (0-16 years) of the pediatric population studied. This finding may be explained by the high prevalence of dental caries and unsatisfactory oral health conditions, unfortunately still common in less developed countries. ${ }^{6}$

The third most prevalent group in this study were benign neoplasms, which comprise a heterogeneous group of pathological disorders characterized by histopathological variations and distinct clinical behaviors..$^{18}$ The diagnosis of most neoplasms is based on histopathological analyses using conventional staining techniques. However, in some situations, specific techniques such as immunohistochemistry are necessary. Fortunately, many of these lesions, especially ameloblastomas and odontogenic myxomas, are benign. ${ }^{28,29}$ In the present sample, odontoma was the most frequent neoplasm, as also reported in other studies. ${ }^{8,9,12,18}$ These lesions are mixed epithelial and mesenchymal tumor-like malformations (hamartomas) composed of hard and soft dental tissue. ${ }^{20}$ Odontomas are mainly diagnosed in children, adolescents and 
young adults, and show no gender predilection. ${ }^{9}$ In our sample, 53 patients were diagnosed in the 9-12year age range. In this study, the frequency of this disease in the Brazilian population corroborates the findings of Soluk Tekkesin et al. ${ }^{31}$ from Turkey, who diagnosed 160 odontomas, $36.8 \%$ of which were in the pediatric population.

The most common non-neoplastic bone diseases were benign fibro-osseous lesions. Their diagnosis is challenging and established by combining clinical and radiographic data, which due to histopathological similarities may yield confusion and be difficult to differentiate from other lesions. ${ }^{32,33}$ These lesions present a wide range of biological behaviors, calling for individually tailored treatments to be considered. ${ }^{33,34}$ In the present study, these lesions were more frequent in the maxilla of girls aged 9 to 12 years, in contrast to study reports in the literature, except for the age range. $33,35,36$

In addition, approximately one out of every 100 children was diagnosed with a malignant neoplasm, and four of the 23 cases of these neoplasms were oral squamous cell carcinomas. The mean age of patients with malignant neoplasms was 7.0 years, and that of patients with squamous cell carcinomas was 7.2 years. This lesion is uncommon in this age group; however, some studies have reported similar findings of carcinomas in the child population. ${ }^{8,23,27}$ Smoking and alcohol consumption are factors predisposing to this type of cancer, which may also be associated with human papilloma virus (HPV) infection. ${ }^{37}$ However, none of the children in the present sample had a history of smoking or consumption of alcoholic beverages, or a medical history of HPV. Thus, in the current case, other etiologic factors, such as nutritional deficiencies, viruses, sporadic mutation, and passive smoking could be associated. ${ }^{26,38,39}$ Passive smoke exposure in children contributes significantly to morbidity and mortality. ${ }^{39}$ Exposure to environmental tobacco smoke has been found to be associated with the early development of respiratory diseases, behavioral problems, and an increased risk of childhood cancer. ${ }^{40}$

The prevalence of oral lesions seems to depend on different additional factors. Economic status has an influence on self-care health attitudes. For example, some patients may be reluctant to undergo a biopsy or to accept its importance. The prevalence of oral lesions may differ among patients from different regions of the world, as well as between males and females, and these differences should be further investigated.

\section{Conclusions}

Mucocele was the most frequent disease. Our findings add to the literature on pediatric oral and maxillofacial lesions. The knowledge of oral diseases obtained from biopsy records is important for dentists in general, pediatric dentists and clinicians worldwide, since it provides accurate data for the diagnosis and oral health of pediatric patients. The notification of malignant neoplasms is important for devising preventive measures and making an early diagnosis, as well as for more favorable prognoses, leading to more effective treatments for the population.

\section{Acknowledgements}

This study received the support of the Brazilian National Council for Scientific and Technological Development (CNPq). R.S.G. and R.A.M. are research fellows at CNPq. Mrs. E. Greene provided English editing of the manuscript and Prof. Lucas G. Abreu provided statistical assistance for this study.

\section{References}

1. Lu C, Black MM, Richter LM. Risk of poor development in young children in low-income and middle-income countries: an estimation and analysis at the global, regional, and country level. Lancet Glob Health. 2016 Dec;4(12):e916-22. https://doi.org/10.1016/S2214-109X(16)30266-2
2. Instituto Brasileiro de Geografia e Estatística - IBGE.

[Population projection of Brazil and Federative Units]. Rio de Janeiro: Instituto Brasileiro de Geografia e Estatística; 2017 [access 2017 Jan 27]. Available from: https://www.ibge.gov.br/apps/populacao/projecao/ 
3. United Nations. Population Division. World population prospects 2017. New York: United Nations; 2017 [access 2017 Jan 17]. Available from: https://esa.un.org/unpd/wpp

4. Skinner RL, Davenport WD Jr, Weir JC, Carr RF. A survey of biopsied oral lesions in pediatric dental patients. Pediatr Dent. 1986 Jun;8(3):163-7.

5. Sklavounou-Andrikopoulou A, Piperi E, Papanikolaou V, Karakoulakis I. Oral soft tissue lesions in Greek children and adolescents: a retrospective analysis over a 32-year period. J Clin Pediatr Dent. 2005;29(2):175-8. https://doi.org/10.17796/icpd.29.2.21184130718243r2

6. Jones AV, Franklin CD. An analysis of oral and maxillofacial pathology found in children over a 30 year period. Int J Paediatr Dent. 2006 Jan;16(1):19-30. https://doi.org/10.1111/j.1365-263X.2006.00683.x

7. Lima GS, Fontes ST, de Araújo LM, Etges A, Tarquinio SB, Gomes AP. A survey of oral and maxillofacial biopsies in children: a single-center retrospective study of 20 years in Pelotas-Brazil. J Appl Oral Sci. 2008 Nov-Dec;16(6):397-402. https://doi.org/10.1590/S1678-77572008000600008

8. Wang YL, Chang HH, Chang JY, Huang GF, Guo MK. Retrospective survey of biopsied oral lesions in pediatric patients. J Formos Med Assoc. 2009 Nov; 108(11):862-71. https://doi.org/10.1016/S0929-6646(09)60418-6

9. Martins-Filho PR, Santos TS, Piva MR, Silva HF, Silva LC, Mascarenhas-Oliveira AC et al. A multicenter retrospective cohort study on pediatric oral lesions. J Dent Child (Chic). 2015 May-Aug;82(2):84-90.

10. Ha WN, Kelloway E, Dost F, Farah CS. A retrospective analysis of oral and maxillofacial pathology in an Australian paediatric population. Aust Dent J. 2014 Jun;59(2):221-5. https://doi.org/10.1111/adj.12174

11. Cavalcante RB, Turatti E, Daniel AP, Alencar GF, Chen Z. Retrospective review of oral and maxillofacial pathology in a Brazilian paediatric population. Eur Arch Paediatr Dent. 2016 Apr;17(2):115-22. https://doi.org/10.1007/s40368-015-0217-5

12. Vale EB, Ramos-Perez FM, Rodrigues GL, Carvalho EJ, Castro JF, Perez DE. A review of oral biopsies in children and adolescents: A clinicopathological study of a case series. J Clin Exp Dent. 2013 Jul;5(3):e144-9. https://doi.org/10.4317/jced.51122

13. Pessôa CP, Alves TD, Santos NC, Santos HL, Azevedo AC, Santos JN et al. Epidemiological survey of oral lesions in children and adolescents in a Brazilian population. Int J Pediatr Otorhinolaryngol. 2015 Nov;79(11):1865-71. https://doi.org/10.1016/j.ijporl.2015.08.026

14. Ataíde AP, Fonseca FP, Silva ARS, Jorge Júnior J, Lopes MA, Vargas PA. Distribution of oral and maxillofacial lesions in pediatric patients from a Brazilian southeastern population. Int J Pediatr Otorhinolaryngol. 2016 Nov;90:241-4. https://doi.org/10.1016/j.ijporl.2016.09.027

15. Lapthanasupkul $P$, Juengsomjit $R$, Klanrit $P$, Taweechaisupapong $S$, Poomsawat $S$. Oral and maxillofacial lesions in a Thai pediatric population: a retrospective review from two dental schools. J Med Assoc Thai. 2015 Mar;98(3):291-7.
16. Majorana A, Bardellini E, Flocchini P, Amadori F, Conti G, Campus $G$. Oral mucosal lesions in children from 0 to 12 years old: ten years' experience. Oral Surg Oral Med Oral Pathol Oral Radiol Endod. 2010 Jul;110(1):e13-8. https://doi.org/10.1016/j.tripleo.2010.02.025

17. Al Yamani AO, Al Sebaei MO, Bassyoni LJ, Badghaish AJ, Shawly $\mathrm{HH}$. Variation of pediatric and adolescents head and neck pathology in the city of Jeddah: A retrospective analysis over 10 years. Saudi Dent J. 2011 Oct;23(4):197-200. https://doi.org/10.1016/i.sdentj.2011.09.002

18. Jaafari-Ashkavandi Z, Ashraf MJ. A clinico-pathologic study of 142 orofacial tumors in children and adolescents in southern iran. Iran J Pediatr. 2011 Sep;21(3):367-72.

19. Zuñiga MD, Méndez CR, Kauterich RR, Paniagua DC. Paediatric oral pathology in a Chilean population: a 15 -year review. Int J Paediatr Dent. 2013 Sep;23(5):346-51. https://doi.org/10.1111/j.1365-263X.2012.01245.x

20. El-Naggar AK, Chan JK, Grandis JR, Takata T, Slootweg PJ. World Health Organization classification of head and neck tumours. 4th ed. Lyon: IARC Press; 2017.

21. Neville BW, Damm DD, Allen CM, Chi AC. Oral and maxillofacial pathology. 4th ed. St. Louis: Elsevier; 2015.

22. Cavalcante ASR, Marsilio AL, Kühne SS, Carvalho YR. Oral lesions found in children and adolescents. Pós-Grad Rev Fac Odontol São José dos Campos. 1999 Jan-Jun;2(1):67-75.

23. Maia DM, Merly F, Castro WH, Gomez RS. A survey of oral biopsies in Brazilian pediatric patients. ASDC J Dent Child. 2000 Mar-Apr;67(2):128-31.

24. Sousa FB, Etges A, Corrêa L, Mesquita RA, Araújo NS. Pediatric oral lesions: a 15 -year review from São Paulo, Brazil. J Clin Pediatr Dent. 2002;26(4):413-8. https://doi.org/10.17796/icpd.26.4.47n1670jr961x566

25. Bessa CF, Santos PJ, Aguiar MC, do Carmo MA. Prevalence of oral mucosal alterations in children from 0 to 12 years old. J Oral Pathol Med. 2004 Jan;33(1):17-22. https://doi.org/10.1111/j.1600-0714.2004.00200.x

26. Santos PJ, Bessa CF, Aguiar MC, Carmo MA. Cross-sectional study of oral mucosal conditions among a central Amazonian Indian community, Brazil. J Oral Pathol Med. 2004 Jan;33(1):7-12. https://doi.org/10.1111/j.1600-0714.2004.00003.x

27. Albright JT, Topham AK, Reilly JS. Pediatric head and neck malignancies: US incidence and trends over 2 decades. Arch Otolaryngol Head Neck Surg. 2002 Jun;128(6):655-9. https://doi.org/10.1001/archotol.128.6.655

28. Aregbesola SB, Ugboko VI, Akinwande JA, Arole GF, Fagade OO. Orofacial tumours in suburban Nigerian children and adolescents. Br J Oral Maxillofac Surg. 2005 Jun;43(3):226-31. https://doi.org/10.1016/j.bjoms.2004.11.006

29. Guerrisi M, Piloni MJ, Keszler A. Odontogenic tumors in children and adolescents. A 15 -year retrospective study in Argentina. Med Oral Patol Oral Cir Bucal. 2007 May;12(3):E180-5. 
30. Prockt AP, Schebela CR, Maito FD, Sant'Ana-Filho M, Rados PV. Odontogenic cysts: analysis of 680 cases in Brazil. Head Neck Pathol. 2008 Sep;2(3):150-6. https://doi.org/10.1007/s12105-008-0060-7

31. Soluk Tekkesin M, Pehlivan S, Olgac V, Aksakallı N, Alatli C. Clinical and histopathological investigation of odontomas: review of the literature and presentation of 160 cases. J Oral Maxillofac Surg. 2012 Jun;70(6):1358-61. https://doi.org/10.1016/i.joms.2011.05.024

32. Mafee MF, Yang G, Tseng A, Keiler L, Andrus K. Fibroosseous and giant cell lesions, including brown tumor of the mandible, maxilla, and other craniofacial bones. Neuroimaging Clin N Am. 2003 Aug;13(3):525-40. https://doi.org/10.1016/S1052-5149(03)00040-6

33. Kolomvos $N$, Theologie-Lygidakis N, Christopoulos $P$, latrou I. Benign fibro-osseous lesions of the jaws in children. A 12-year retrospective study. J Craniomaxillofac Surg. 2013 Oct;41(7):574-80. https://doi.org/10.1016/i.jcms.2012.11.029

34. Papadaki ME, Troulis MJ, Kaban LB. Advances in diagnosis and management of fibro-osseous lesions. Oral Maxillofac Surg Clin North Am. 2005 Nov;17(4):415-34. https://doi.org/10.1016/i.coms.2005.06.004

35. Alsharif MJ, Sun ZJ, Chen XM, Wang SP, Zhao YF. Benign fibro-osseous lesions of the jaws: a study of 127 Chinese patients and review of the literature. Int J Surg Pathol. 2009 Apr;17(2):122-34. https://doi.org/10.1177/1066896908318744

36. Iatrou I, Theologie-Lygidakis N, Tzerbos F, Schoinohoriti OK. Oro-facial tumours and tumour-like lesions in Greek children and adolescents: an 11 -year retrospective study. J Craniomaxillofac Surg. 2013 Jul;41(5):437-43. https://doi.org/10.1016/i.jcms.2012.11.010

37. Saulle R, Semyonov L, Mannocci A, Careri A, Saburri F, Ottolenghi $L$ et al. Human papillomavirus and cancerous diseases of the head and neck: a systematic review and meta-analysis. Oral Dis. 2015 May;21(4):417-31. https://doi.org/10.1111/odi.12269

38. Scully C. Challenges in predicting which oral mucosal potentially malignant disease will progress to neoplasia. Oral Dis. 2014 Jan;20(1):1-5. https://doi.org/10.1111/odi.12208

39. Cheraghi M, Salvi S. Environmental tobacco smoke (ETS) and respiratory health in children. Eur J Pediatr. 2009 Aug;168(8):897-905. https://doi.org/10.1007/s00431-009-0967-3

40. John EM, Savitz DA, Sandler DP. Prenatal exposure to parents' smoking and childhood cancer. Am J Epidemiol. 1991 Jan;133(2):123-32. https://doi.org/10.1093/oxfordjournals.aje.a115851 